\title{
INDIAN INLAND WATER AND PARTS OF ANTARCTIC ICE SHEET ELEVATION AND ICE SHEET VELOCITY MONITORING USING ALTIMETRY AND SAR BASED DATASETS
}

\author{
Praveen K. Thakur ${ }^{*}$, Arpit Chouksey ${ }^{1}$, Praveen Kalura ${ }^{1}$, Surajit Ghosh ${ }^{3}$, Pankaj Dhote ${ }^{1}$, Ashit Swain ${ }^{4}$, Munish Kalia ${ }^{5}$, Vaibhav \\ Garg $^{1}$, Bhaskar R Nikam ${ }^{1}$, Pradeep Kumar ${ }^{4}$, S.P. Aggarwal ${ }^{1}$, Prakash Chauhan ${ }^{1}$ and A. Senthil Kumar ${ }^{1}$ \\ ${ }^{1}$ Indian Institute of Remote Sensing, Dehradun, India - (praveen, vaibhav, bhaskarnikam, arpit, pdh, spa, prakash)@iirs.gov.in \\ ${ }^{2}$ Centre for Space Science and Technology Education in Asia Pacific - (CSSTEAP), IIRS campus Dehradun (senthil@iirs.gov.in) \\ ${ }^{3}$ National Institute of Technology Duragapur, West Bengal, India - (surajitghosh.ind@gmail.com) \\ ${ }^{4}$ Geological Survey of India, Gangtok, Sikkim, and Faridabad, India - (swain21@ gmail.com; pkumar.iitkgp@ gmail.com) \\ ${ }^{5}$ National Institute of Technology, Hamirpur, Himachal Pradesh, India - (munishkalia007@ gmail.com)
}

\section{Commission V, SS: Natural Resources Management}

KEYWORDS: Altimetry, Ice sheet, SARAL-ALTIKA, DInSAR, Water Level

\begin{abstract}
:
The monitoring of inland water and continental ice sheets is very important from water management and global climate related studies. The current study utilizes the SGDR data from Saral-Altika during 2013-2017 to estimate and monitor water level in 24 major reservoirs of India. The $\mathrm{R}^{2}$ value for majority of reservoirs was more than 0.99 and RMSE error value also was less than 0.40 $\mathrm{m}$. In addition, wide rivers of India such as Mahanadi River, was also monitored using Altika data covering part of Mahanadi River from Khairmal to Naraj gauging sites during 2013-2016 time period. One dimensional hydro-dynamic (1D-HD) model was setup for this part of river to generate river Discharge at virtual gauge. The part of Antarctic ice sheet South of Indian research station Maitri, East Antarctica, was studied for ice sheet elevation changes using ground based stake network as well as space based altimeter/LIDAR datasets during 2003-2017 time period. 2003-2009 time was used for getting elevation changes using Icesat-1 level 2 altimetry product, and Geophysical Data Record (GDR) data from Altika was used with slope correction from 2013-2016 time period. An extensive network of ground based stake networks were used for validating the derived elevation changes. The ice sheet and glacier line of site velocity was estimated using Sentinel-1 based InSAR data with 6 to 12 day time interval data sets for year 2016 and 2017. The derived glacier velocity was comparable with optical image (Landsat-8) based glacier velocity for same year and also with historical Radarsat-1 based glacier velocity results.
\end{abstract}

\section{INTRODUCTION}

The inland water such as reservoirs, rivers, and wetlands represents the surface water component of hydrological cycle. This surface water acts as storage for various uses, such as irrigation, drinking water, hydro-power, industrial use, recreation and overall ecological health of a river or catchment. Accurate monitoring of water storage variation of water bodies is essential for water resources management. Water Level data is an important parameter for regional and global studies of reservoirs, Surface water storage changes and study of hydrological cycle. The water level is traditionally measured by means of in-situ gaging stations, but lack of sufficient in-situ measurement of the water level is the major limitation. Moreover the data access to these measurement is very difficult. The regular mapping and monitoring the surface extent of such water bodies is feasible with remote sensing, and satellite based Altimeter represents a unique opportunity to monitor the water level in such water bodies. Similarly, the vast Antarctic ice sheet can be monitored using remote sensing and its ice elevation changes can be estimated using space based altimeter or LIDARs and ice sheet velocity can be estimated using interferometric SAR datasets.

Remote sensing techniques such as Satellite radar altimetry can prove to be an economical alternative. It was initially designed for measurements of sea surface height, ocean circulation and sea level, but recently it has been demonstrated to be applicable to non-ocean surfaces as well. In the past few years, satellite altimetry is being used for measurement of water level of inland water bodies such as lakes, reservoirs and rivers (e.g. Birkett, 1995; Crétaux and Birkett, 2006 and Crétaux et al., 2011, , Koblinsky et al.,1993, Ghosh et al. 2015, Khandelwal et. al. 2017). GEOS-III launched in 1975, was the first satellite altimeter, followed by Seasat in 1978. Since 1990s, several satellite altimetry missions have been providing data for inland water studies, (ERS-1, 1991-2000), TOPographic Experiment/Poseidon (TOPEX/Poseidon or T/P, 1992-2005), ERS-2 (1995-2011), Geosat Follow-On (GFO, 1998-2008), Envisat (2002-2012), Jason-1 (J1, 2001-2013), Jason-2 (J2, 2008-present), CryoSat-2 (2010-present) and SARAL (Satellite with ARgos and ALtiKa) (2013-present), Sentinel-3A (2016present) and Sentinel-3B (2018-present).

Altimetry technique has certain advantages such as Global coverage, trans boundary water bodies monitoring, economical source of information etc. but it also has certain limitations such as limited spatial coverage of worldwide loss and complex shape of the echoes and rapidly varying topography. Nevertheless, Altimetry is the only source of information for most lakes in remote areas.

In Last few years investigators have used altimeter datasets to calculate surface elevation changes in the polar ice sheets. These results demonstrated the important role that satellite

\footnotetext{
* Corresponding author
} 
altimetry can play in change detection in the ice-sheets related to global climate change. (Zwally et al. 1989, Thomas 1991, Bamber 1995)

Therefore, the objectives of this work is as follows Therefore, the objectives of this work is as follows to Show the effectiveness of altimetry data to monitor inland water bodies such as reservoirs and rivers where gauge data is not sufficient. Application of altimetry data is also used to monitor the ice sheet elevation change over a part of Antarctica region. Due to in difficulty in accessibility to this remote part Altimetry data could be an important source of information.

\section{DATA USED AND STUDY AREA}

\subsection{SARAL/AltiKa data}

Altimetric measurements around 32 cycles were retrieved for selected Indian reservoir during April, 2013-March, 2016 using SARAL/AltiKa GDR data. Cloud free Landsat 8 images of the nearest dates to SARAL/AltiKa acquisitions were used to ensure that the selected measurement points were located within the water area. The altimetry data was downloaded from AVISO (www.aviso.altimetry.fr). Landsat 8 data is used to check that altimeter reading is within the body of reservoir.

\subsection{India- WRIS database}

For the validation of the retrieved water level heights from satellite altimetry in-situ water level time series was used which is available from INDIA-WRIS portal (www.indiawris.nrsc.gov.in), a Web based Water Resources Information System on Geographical Information System platform, which was launched by the Central Water Commission (CWC) jointly with National Remote Sensing Centre (NRSC) on 7th December, 2010.

\subsection{Icesat-1, Landsat-8, and Sentinel-1 SAR datasets}

Landsat Image for 26 Oct 2013 is used as background image for Depositional change in selected sites using ICESat data. Ice Surface velocity near Maitri, East Antarctica (Figure 2) is done using Landsat Image of 27 December 2016. Ice sheet elevation changes study is done using ground based stake network (20162017) as well as space based altimeter/LIDAR datasets during 2003-2017 time period. 2003-2009 time was used for getting elevation changes using Icesat-1 GLAS GLA14 level 2 altimetry product, and GDR data from Altika was used with slope correction from 2013-2017 time period. An extensive network of ground based stake networks were installed by Geological Survey of India (GSI) and IIRS during $36^{\text {th }}$ and $37^{\text {th }}$ Indian Scientific Expedition to Antarctic (ISEA) in this area along with repeat DGPS readings during summer of 2016-17 and 2017-18 was used for validating the derived elevation changes. The ice sheet and glacier line of site velocity was estimated using Sentinel-1 based InSAR data with 6 to 12 day time interval data sets for year 2016 and 2017. The derived glacier velocity was comparable with optical image (Landsat-8) based glacier velocity for same year and also with historical Radarsat-1 based glacier velocity results.

\subsection{Study area}

For inland water bodies monitoring few Indian reservoirs were selected from different parts of India. Only major reservoirs with sufficient Pass of Saral tracks were selected (10 in nos.). In the present study, river reach in the Mahanadi system extending over a length of $106 \mathrm{~km}$ from Khairmal to Munduli is considered for analysis. The part of Antarctic ice sheet South of Indian research station Maitri, located in Princes Astrid Coast of Central Droning Maud Land (cDML) lying between $5^{\circ}$ and $20^{\circ} \mathrm{E}$, East Antarctica, was studied for ice sheet elevation and velocity change study.



Figure 1. Mahanadi River with Saral-altika tracks

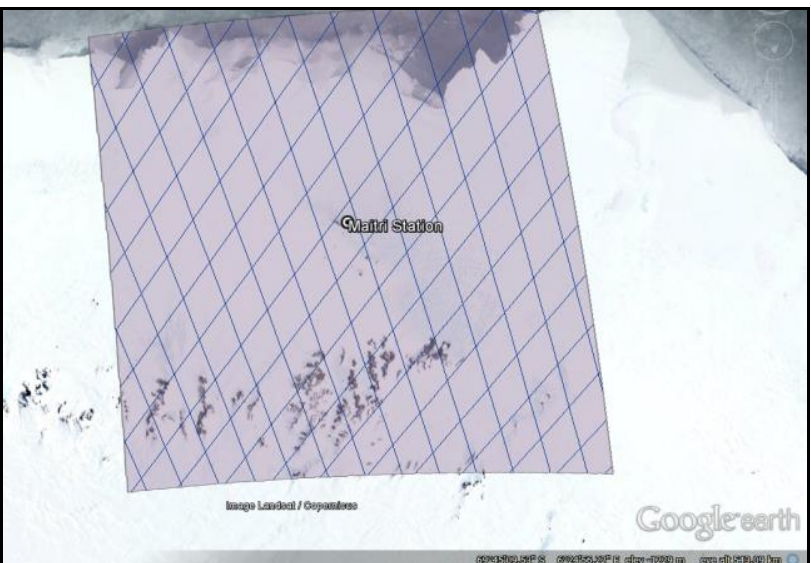

Figure 2. Region of Antartica used for Saral data processing and ice sheet elavation, velocity study and ground survey.

\section{METHODOLOGY}

The methodology is divided into two parts, first the altimetry based water level and discharge estimation for Indian inland water is done using approach given in figure 3 and sub-section 3.1. Next, the elevation and velocity study in parts of Antarctica was done using approach given in figure 4 and sub-section 3.2. The details of each approaches are as follows.

\subsection{Inland Water Bodies Elevation and River Discharge}

The Saral-Altika GDR data was first downloaded from AVISO (ftp://avisoftp.cnes.fr) site, and the data from cycle 1-35 is normal Altika data with repeat pass (April 2013 to June 2016), but after data, from cycle 100 onwards (July 2016 to till now), Altika data with drifting orbit is used. This data was read and processed with python based Basic Radar Analysis Tool (BRAT) of European Space Agency (ESA), to derive the final water level or ice sheet elevation using basic range and various range corrections (Ghosh et al., 2017). The Ice-1 re-tracker is used for deriving the water level and ice elevation data (Martin et al., 1983; Wingham et al., 1986; Frappart et al., 2006). 


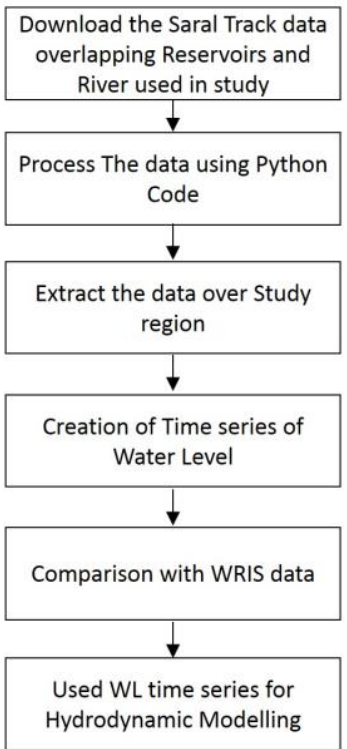

Figure 3. Methodology flowchart for Inland waterbodies water level and river discharge estimation

\subsection{Ice Sheet Study for Elevation and Velocity}

The ice elevation was estimated using same approach as given in figure 3. Brief methodology for DInSAR based method ice sheet velocity is shown in Figure 4.

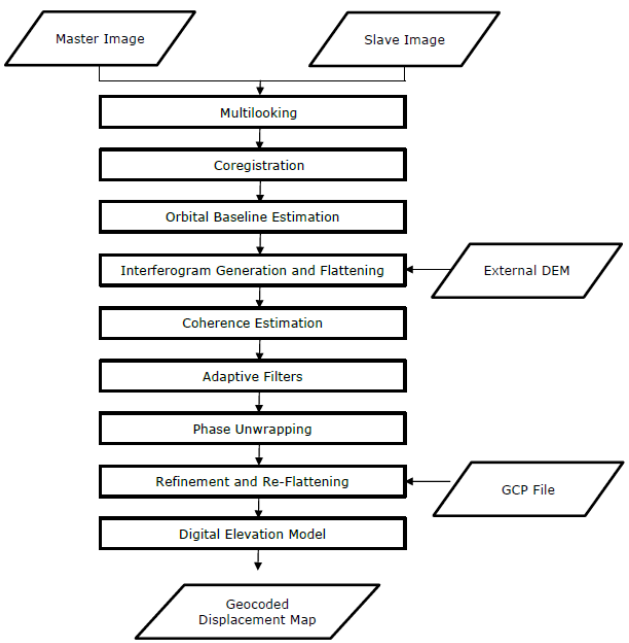

Figure 4. DInSAR based method ice sheet velocity estimation (Adopted from Sood, 2015 and Thakur et al., 2016)

The ice sheet velocity was also estimated using co-registered optical image based feature tacking method (Leprince et al., 2007).

\section{RESULTS AND DISCUSSIONS}

The results are divided into 3 sub-sections, first results of altimeter based results of water level and river flow in few select reservoir and river of India is given. Next, the Altika and icesat-1 based ice sheet elevation from 2013-2016 time is presented. The next sub-section presents the optical and SAR based ice sheet/glacier velocity results for area South and North of Maitri, Antarctica, showing Somovken ice stream of East Antarctica.

\subsection{Inland water level and river discharge estimation using altimetry}

In case of Inland waters, more than 24 reservoirs and three high altitude lakes were studied for water level estimation with Altika data. Out of these selected reservoirs, 4 reservoirs suffered from data loss those reservoirs are Balimela Reservoir Bargi Rani Reservoir Bhakra Reservoir, Sardar Sarovar and Tehri Reservoir. Validation of satellite altimetry data with corresponding ground measured data is also important for reservoir monitoring through Altimetry data. The processed altimetry water level needs to be corrected for the systematic shift which is mainly due to different datum system and also the location of the gauge station. Due to the 35 days temporal resolution of SARAL/AltiKA we can miss the variation in water level in case of heavy rainfall as for Hasdeo reservoir during Sept-Oct 2013. In addition, during dry season with low water level we can get error in altimetry retrieved water level.

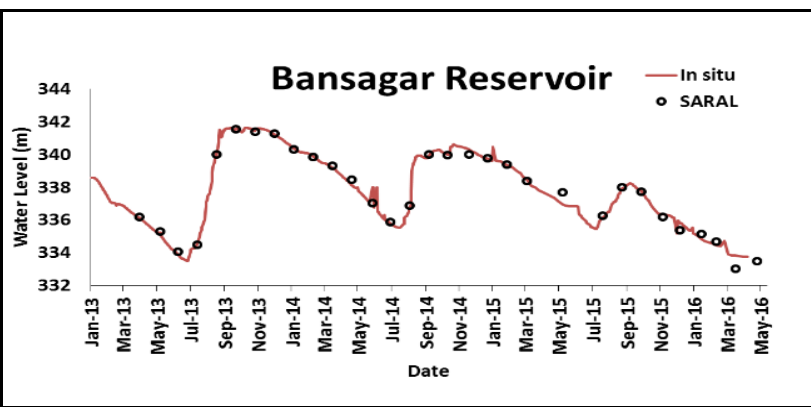

Figure 5. Altika water level time series for Bansagar (2013-18).

Figure 5 shows the water Level Time series of one of the reservoirs, Bansagar, which is located in central India. Only for this reservoir time series is shown so as to compare the trend as this reservoir water level is comparatively closer than all other reservoirs from 2013-2018. The drifting data based WL (figure 5) has less accuracy as compared to normal repeat track data.

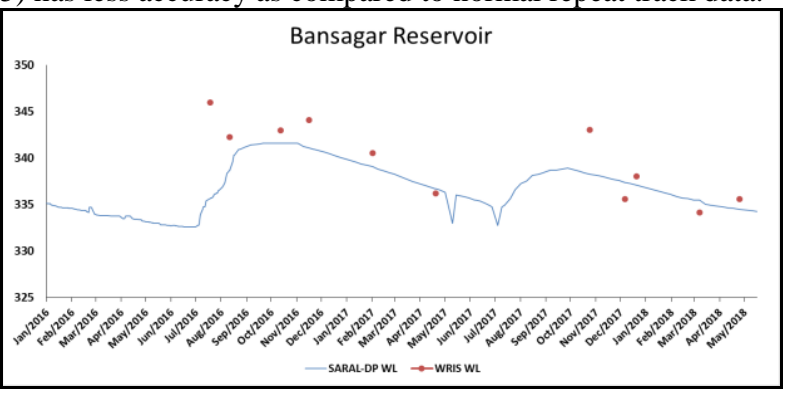

Figure 6. Saral Altika (drifting orbit, July-2016 to May-2018) water level time series for Bansagar



Figure 7. Accuracy of Altika estimated and field measured water level for Bansagar reservoir (2013-2018). 
The $\mathrm{R}^{2}$ value for majority of reservoirs was more than 0.99 and RMSE error value also was less than $0.40 \mathrm{~m}$ as mentioned in previous studies. But Shivaji reservoir showed large RMSE value of $1.64 \mathrm{~m}$ which is yet to be explained. For Bansagar Reservoir the value of average standard deviation was found to be $0.17 \mathrm{~m}$. which mean that within one cycle the standard deviation of all the water level values which was retrieved from the target was $0.17 \mathrm{~m}$ (figure 7). Some reservoirs such as Ranjit sagar Reservoir and Rihand reservoir show some problem with the SARAL/Altika data. Few cycles captured the exact water level but the variation of up to $50 \mathrm{~m}$ (Rihand Reservoir) to 140 $\mathrm{m}$ (Ranjit sagar reservoir) is also observed.

In addition to the monitoring of water level of reservoirs, few ungauged high altitude Himalayan lakes were also monitored for water level variations using Altika data. Two Himalayan lakes selected are, Mansarover Lake in Tibet and other is Pangong Lake along Indo-China border in J\&K state of India. Both of these lakes are selected due to their large area coverage, difficult terrain and in-accessibility of these lakes. Water level in these lake were monitored from April 2013 to April 2016, with estimated water level variations of 0.2 to $1.2 \mathrm{~m}$. The altimeter data from Sentinel-3A satellite was used for WL estimation in few reservoirs such as Ukai and Ghandi Sagar from 2016 to 2018 .

In next part, altimetry based WL is used with rating curve approach for estimating the river discharge in few virtual gaging sites of Mahanadi River. The Rating curve was generated at Tikarpara site (Figure 8) using in-situ data because only this site was having stage-discharge data available from India-WRIS portal.

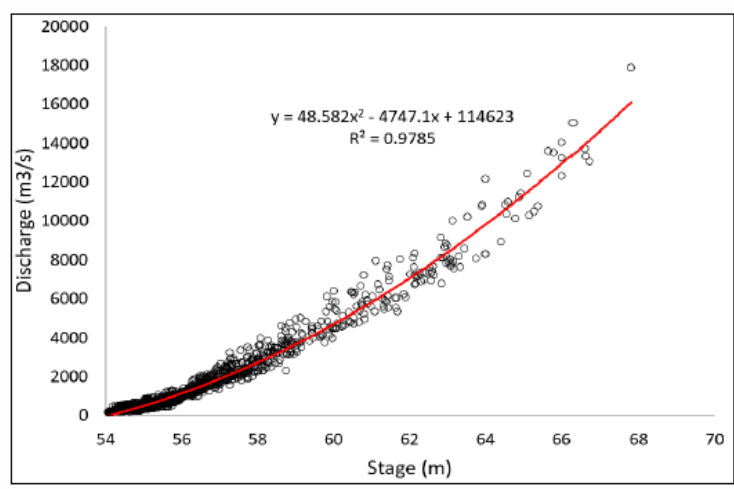

Figure 8. Rating curve for Tikarapara station of Mahanadi River

Then The HEC-RAS generated rating curve was compared with in situ rating curve and both curve were found to be similar. So we can conclude that we can use HEC-RAS generated rating curve (figure 9) to estimate discharge if the in situ rating curve is unavailable. The $\mathrm{R}^{2}$ value for discharge estimation using insitu rating curve and HEC-RAS rating curve was 0.99 and also error in discharge estimation was less $2 \%$ with the mean in-situ discharge.

The validated HEC-RAS model is used to generate the rating curve at the virtual stations. These rating curves were further used to estimate discharge at these virtual stations. Figure 10 shows the estimated river discharge at one of the Altika Virtual Gauge near Tikarpara.

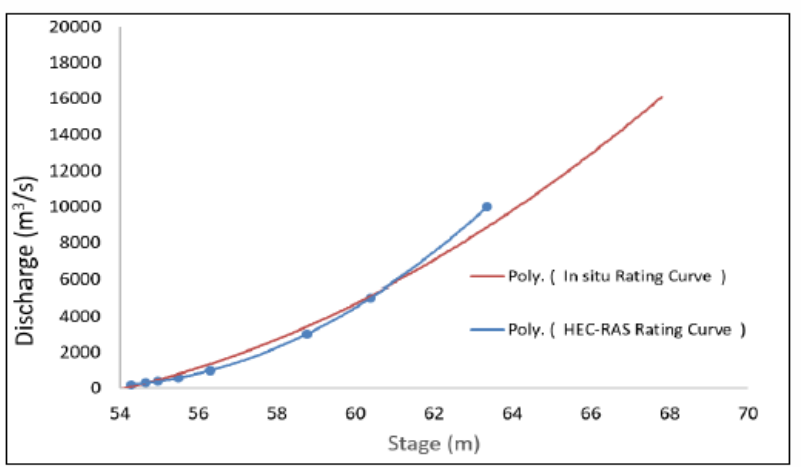

Figure 9. Comparion of In-situ and HD model based rating curve

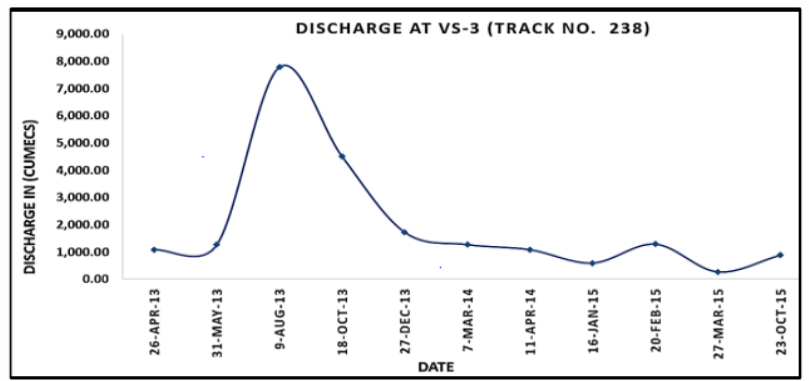

Figure 10. Estimated River discharge (2013-2015) at one of Altika virtual gauge near Tikarpara, Mahanadi River

\subsection{Altika based Ice elevation estimation and changes near, Maitri, East Antarctica}

Eastern Part of Antartica, near Maitri station was selected for eleveation study ice surface. The surface profile was generated using IDW interpolation technique. And the elevation profile along four track viz. 12, 203, 556 and 747 is plotted for year 2013 and 2016 as shown in figure 11 and figure 12 respectively.

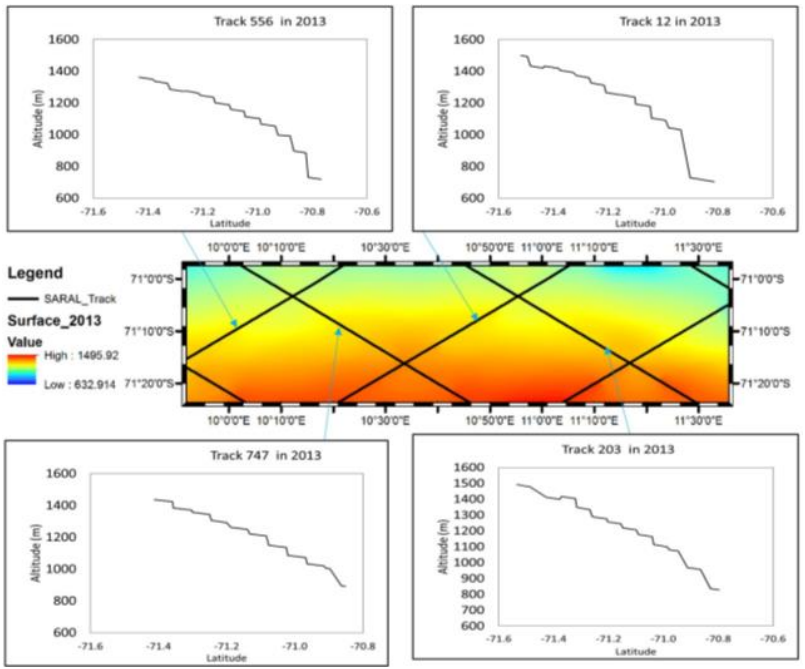

Figure 11. Ice Sheet Elevation profile for Dec.2013-Jan2014 


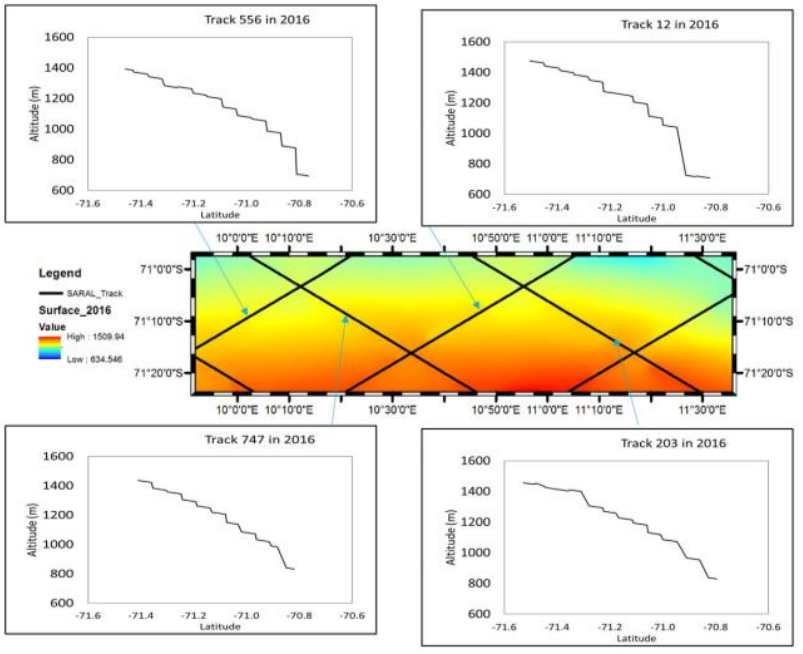

Figure 12. Ice Sheet Elevation profile for January 2016

For the purpose to show change in elevation profile they were plotted together for the four selected track and as seen in figure 12. As per this data, following elevation changes are observe in the cDML of East Antarctica. The mean elevation changes (after removing spurious change values of $+/-20 \mathrm{~m}$ ) for track numbers 556, 12, 747 and 203 during 2014-2016 time periods comes as $+2.71,-4.45 \mathrm{~m}+1.78 \mathrm{~m}$, and $-2.40 \mathrm{~m}$ respectively. The change in the most of tracks shows increase in ice elevations (+) as we move towards South of Maitri, i.e., towards Continental ice sheet and decrease in ice elevation as we move from South to North, i.e., near to Maitri station. The same results are seen during two field campaigns in ISEA-36 and 37 by joints teams of IIRS and GSI. The sentinel-3A and 3B altimetry data (https://sentinels.copernicus.eu/web/sentinel/missions/sentinel3) will be used after July 2016, as Altika shifted into drifting orbit after July 2016 to continue the altimetry based ice sheet elevation change studies.

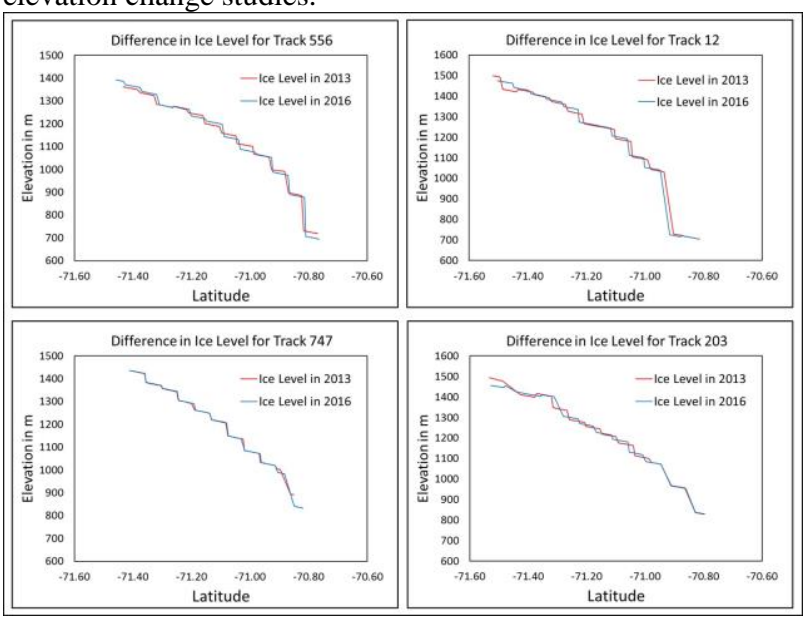

Figure 12. Ice Sheet Elevation profile difference for 2013-2016.

4.3 Landsat-8 and Sentienl-1 based Ice surface velocity and GLAS based elevation estimation near, Maitri, East Antarctica

Ice sheet and ice stream velocity estimation was done using optical image based feature tracking methods and DInSAR based techniques, as given in methodology section. The ice sheet/stream velocity is estimated to be in range of $0-150$ $\mathrm{m} / \mathrm{year}$, with highest velocity for East Ice sheet near Maitri, medium for Somovken ice stream, lowest for central ice sheet of
cDML, East Antarctica, which is similar to the other globally reprted results (Rignot et al., 2011; Rignot et al., 2017).

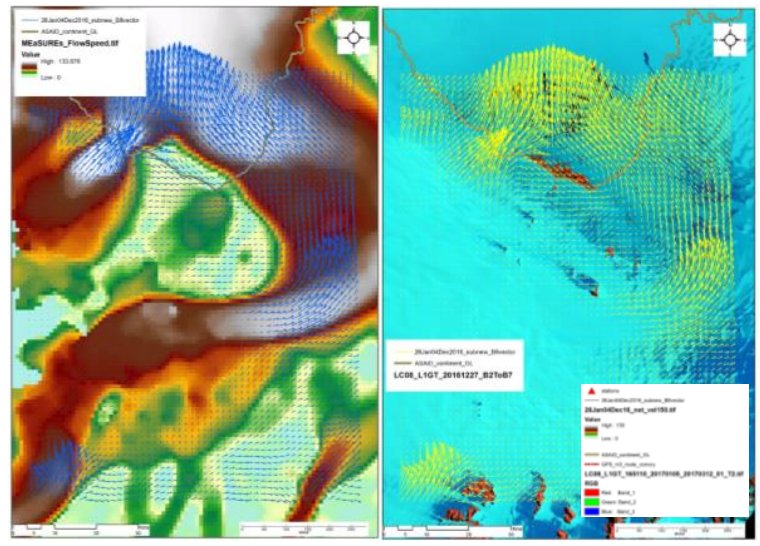

Figure 13. Landsat-8 based ice sheet velocity for cDML and Somovken ice stream for year 2016



Figure 14. Ice sheet velocity using Sentinel-1 based DInSAR data for 18-30 September 2016, with field survey track.

The area of field survey shown in figure 14 was covered for detailed field survey by joint science teams of IIRS-ISRO, Dehradun and GSI, Polar Division, Faridabad during ISEA-36 and ISEA-37 (Swain et. al., 2017; Thakur et al., 2017).

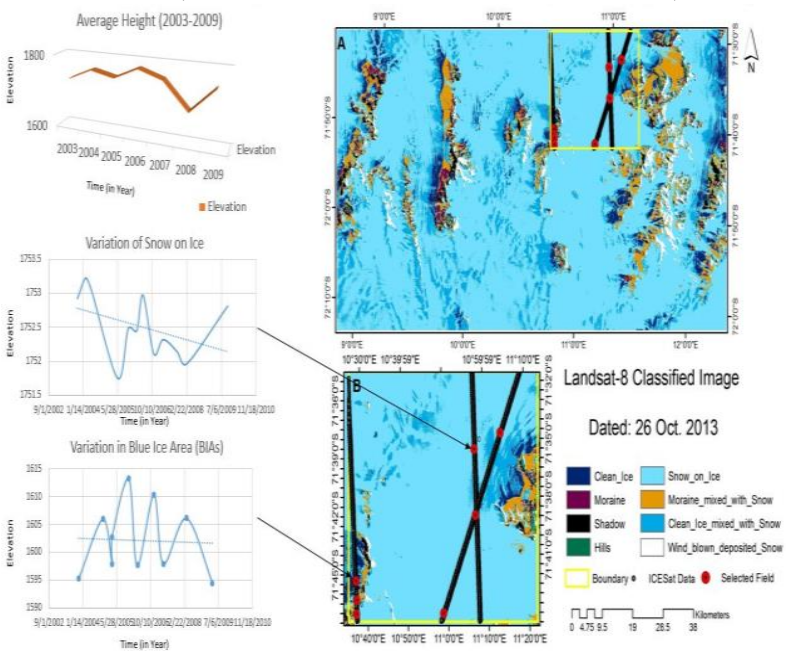

Figure 15. Ice sheet elevation changes with IceSat-1 data. 


\section{CONCLUSIONS}

Altimetry-derived water level/discharge in conjunction use of the hydrodynamic model may accommodate to get the status of various classified and unclassified river basins of world, especially in data sparse situations. It could also be a complementary tool for monitoring and assess the surface water resources of India, even for themost remote part of this country.

Water levels time series obtained with SARAL/AltiKa altimeters over 28 reservoirs of various sizes are calculated and compared to in situ observations. SARAL/AltiKa measurements tend to be extremely well correlated with in situ measurements. In this study the result comparison is made by calculating the correlation and root mean square error (RMS) between SARAL/AltiKa time series and in situ water levels for Indian Reservoirs. There are still some challenges in satellite altimetry application in wetlands. First, given the repeat cycles and the spatial coverage of current altimeters, many Lakes and Reservoirs are still not covered. Second, the frequent changes of water surface area and the coarse spatial resolution of altimetry would likely make some altimetry data invalid for inland water application, especially in the low water period. Most researchers have focused on the difference in elevation from mean rather than absolute water level. This approach can also give the variation in the reservoir water level.

Satellite Altimetry could be a complementary tool for monitoring and assess the surface water resources of India, even for the most remote part of this country. Also upcoming swath altimetry, SWOT of NASA-CNES-CSA will be extremely useful for monitoring small waterbodies. It is also suggested to have multiple altimeters in a constellation with SARAL/ AltiKa type of instruments for a better understanding of inland hydrology.

The vast polar ice sheets are important components of Earth water and energy cycle, which can be monitored regularly at continental scale only by space based satellites such as altimeters, LiDARs, SAR and other RS sensors. The present study has highlighted usefulness of Altika altimeter as well as Icesat-1 LIDAR for observing and monitoring the ice surface elevation. In future the, data from IcesAt-2, which was launched on 15 September 2018 by NASA (https://icesat2.gsfc.nasa.gov/), and Sentinel-3 altimeter will be used to monitor the ice sheet elevation regularly. The ice velocity estimation with Landsat and Sentinel-1 will be continued and algorithms will be refined so that they can be easily applied to the up-coming NASA-ISRO SAR (NISAR) mission (https://nisar.jpl.nasa.gov/). The extensive field network of stakes installed during ISEA-36, 2016-17, South of Maitri, CDML Antarctica, will be used as long term validation site for satellite based ice sheet elevation and velocity products.

\section{ACKNOWLEDGEMENTS}

The authors thanks the ISRO, ESA, NASA and USGS for providing the satellite data used in this project. Dr. Praveen and Mr. Pankaj is also thankful to ISRO and National Centre for Polar and Ocean Research, NCPOR Goa, for giving an opportunity to participate as summer science team member of in $36^{\text {th }}$ and $37^{\text {th }}$ Indian Scientific Expedition to Antarctica (ISEA36 and ISEA-37) during Nov. 2016 to Feb 2017 and 15 November 2017 to 15 January 2018, respectively.

\section{REFERENCES}

Arsen, A., Crétaux, J. F., and Abarca del Rio, R., 2015. Use of SARAL/AltiKa over mountainous lakes, intercomparison with Envisat mission. Marine Geodesy, 38(sup1), 534-548.

Bamber, J. L., 1994. Ice sheet altimeter processing scheme. International Journal of Remote Sensing, 15(4), 925-938.

Birkett, C. M., 1995. The contribution of TOPEX/POSEIDON to the global monitoring of climatically sensitive lakes. Journal of Geophysical Research: Oceans, 100(C12), 25179-25204.

Bonnefond, P.; Willis, J., 2015. Minutes of the 2015 Ocean Surface Topography Science Team Meeting. Available online: http://www.aviso.altimetry.fr/fileadmin/documents/OSTST/OST ST_2015_Meeting_Report.pdf (accessed on 10 Aug 2018).

Calmant, S., Seyler, F., \& Cretaux, J. F., 2008. Monitoring continental surface waters by satellite altimetry. Surveys in geophysics, 29(4-5), 247-269.

Chelton, D.B., Ries, J.C., Haines, B.J., Fu, L.L., Callahan, P.S., 2001. Satellite altimetry. In Satellite Altimetry and Earth Sciences: A Handbook of Techniques and Applications; Fu, L.L., Cazenave, A., Eds.; Academic Press: San Diego, CA, USA, pp. 1-132.

Crétaux, J. F., \& Birkett, C., 2006. Lake studies from satellite radar altimetry. Comptes Rendus Geoscience, 338(14-15), 1098-1112.

Crétaux, J. F., Jelinski, W., Calmant, S., Kouraev, A., Vuglinski, V., Bergé-Nguyen, M. and Maisongrande, P., 2011. SOLS: A lake database to monitor in the Near Real Time water level and storage variations from remote sensing data. Advances in space research, 47(9), 1497-1507.

Dubey, A. K., Gupta, P., Dutta, S., \& Singh, R. P., 2015. Water level retrieval using SARAL/AltiKa observations in the Braided Brahmaputra river, Eastern India. Marine Geodesy, 38(sup1), 549-567.

Fekete, B. M., \& Vörösmarty, C. J., 2007. The current status of global river discharge monitoring and potential new technologies complementing traditional discharge measurements. IAHS publ, 309, 129-136.

Fernandes, M. J., Lázaro, C., Nunes, A. L., \& Scharroo, R., 2014. Atmospheric corrections for altimetry studies over inland water. Remote Sensing, 6(6), 4952-4997.

Frappart, F., Calmant, S., Cauhopé, M., Seyler, F., \& Cazenave, A., 2006. Preliminary results of ENVISAT RA-2-derived water levels validation over the Amazon basin. Remote sensing of Environment, 100(2), 252-264.

Fu, L. L., and Cazenave, A., 2001. Satellite altimetry and earth sciences. Vol. International Geophysical Series 69.

Ghosh, S., Kumar Thakur, P., Garg, V., Nandy, S., Aggarwal, S., Saha, S. K. and Bhattacharyya, S., 2015. SARAL/AltiKa waveform analysis to monitor inland water levels: a case study 
of Maithon reservoir, Jharkhand, India. Marine Geodesy, 38(sup1), 597-613.

Ghosh, S., Thakur, P. K., Sharma, R., Nandy, S., Garg, V., Amarnath, G., and Bhattacharyya, S., 2017. The Potential Applications of Satellite Altimetry with SARAL/AltiKa for Indian Inland Waters. Proceedings of the National Academy of Sciences, India Section A: Physical Sciences, 87(4), 661-677.

Joughin, I., Smith, B.E. and Abdalati, W., 2010. Glaciological advances made with interferometric synthetic aperture radar. Journal of Glaciology, 56(200), pp. 1026-1041.

Khandelwal, A., Karpatne, A., Marlier, M. E., Kim, J., Lettenmaier, D. P., \& Kumar, V., 2017. An approach for global monitoring of surface water extent variations in reservoirs using MODIS data. Remote sensing of Environment, 202, 113-128.

Koblinsky, C. J., Clarke, R. T., Brenner, A. C., \& Frey, H., 1993. Measurement of river level variations with satellite altimetry. Water Resources Research, 29(6), 1839-1848.

Leprince, S., Barbot, S., Ayoub, F. and Avouac, J.P., 2007. Automatic and precise orthorectification, coregistration, and subpixel correlation of satellite images, application to ground deformation measurements. IEEE Trans Geosci Remote Sens., 45(6), pp.1529-1558.

Martin, T.V., Zwally, H.J., Brennerr, A.C., Bindschadler, A., 1983. Analysis and retracking of continental ice sheet radar altimeter waveforms. J Geophys Res 88(C3):1529-1952.

Mouginot, J., B. Scheuchl, and E. Rignot. 2012. Mapping of Ice Motion in Antarctica Using Synthetic-Aperture Radar Data, Remote Sensing. 4. 2753-2767.

Rignot, E., Mouginot, J. and Scheuchl. B., 2011. Ice Flow of the Antarctic Ice Sheet, Science. 333. 1427-1430. https://doi.org/10.1126/science.1208336.

Rignot, E., Mouginot, J. and Scheuchl. B., 2017. MEaSUREs InSAR-Based Antarctica Ice Velocity Map, Version 2. [cDML subset used]. Boulder, Colorado USA. NASA National Snow and Ice Data Center Distributed Active Archive Center. doi: https://doi.org/10.5067/D7GK8F5J8M8R. [Accessed on Sep, 30, 2018].

Scambos, T., Dutkiewicz, M., Wilson, J., and Bindschadler, R., 1992. Application of image cross-correlation to the measurement of glacier velocity using satellite image data, Remote Sensing of Environment, 42, 177-186.

Scambos, T., Fahnestock, M., Moon, T., Gardner, A., and Klinger, M., 2016. Global Land Ice Velocity Extraction from Landsat 8 (GoLIVE), Version 1, NSIDC: National Snow and Ice Data Center, Boulder, Colorado USA.

Schwatke, C., Dettmering, D., Börgens, E., \& Bosch, W., 2015. Potential of SARAL/AltiKa for inland water applications. Marine Geodesy, 38(sup1), 626-643.

Schwatke, C., Dettmering, D., Börgens, E., \& Bosch, W., 2015. Potential of SARAL/AltiKa for inland water applications. Marine Geodesy, 38(sup1), 626-643.
Schwatke, C., et al., 2015. DAHITI-an innovative approach for estimating water level time series over inland waters using multi-mission satellite altimetry. Hydrology and Earth System Sciences, 19.10: 4345-4364.

Swain, A.K., Thakur, P.K., Bal, S.R., Goswami, S., Shah, M.Y., Shrivastava, P.K., Roy, S.K. and Beg, M.J., 2017. Glacial dynamics of Polar ice sheet between Schirmacher Oasis and Wohlthat Mounatins, East Antarctica. In proceedings of National Conference on Polar Sciences, NCPS-2017, during 16-17 May 2017 at NCAOR, Vasco-da-Gama, Goa.

Thakur, P.K., Chouksey, A., Swain, A.K., Sahni, G., Aggarwal, S.P. and Kumar, A.S., 2017. Study of Antarctic Ice Sheet/Sea Ice Features and Glacier Landforms using Satellite Data. In proceedings of National Conference on Polar Sciences, NCPS2017, during 16-17 May 2017 at NCAOR, Vasco-da-Gama, Goa.

Thakur, P.K., Dixit, A., Chouksey, A., Aggarwal, S.P. and Kumar, A.S., 2016. Ice sheet features identification, glacier velocity estimation and glacier zones classification using high resolution optical and SAR data. In: SPIE Asia-Pacific remote sensing conference, April 4-7, 2016 at New Delhi, India, Proceedings of SPIE, 9877: 987719-1-16.

Thomas, R. H., 1991. Polar research from satellites, Oceanographic Institutions, Inc. Washington, DC.

Verron, J., Sengenes, P., Lambin, J., Noubel, J., Steunou, N., Guillot, A., and Murthy, D. R., 2015. The SARAL/AltiKa altimetry satellite mission. Marine Geodesy, 38(sup1), 2-21.

Wingham, D. J., Ridout, A. J., Scharroo, R., Arthern, R. J., \& Shum, C. K. (1998). Antarctic elevation change from 1992 to 1996. Science, 282(5388), 456-458.

Zwally, H. J., Bindschadler, R. A., Brenner, A. C., Major, J. A., \& Marsh, J.G., 1989. Growth of Greenland ice sheet: Measurement. Science, 246(4937), 1587-1589.

Wingham, D.J., Rapley, C.G., Griffiths, H., 1986. New techniques in satellite altimeter tracking systems. In: Proc IGARSS'86 Symposium, Zurich, ESA SP-254, pp 1339-1344.

https://www.aviso.altimetry.fr/es/news/novedades/newsdetail.html?tx_ttnews\%5Btt_news\%5D=1989\&cHash=0aa2e20 $727 \mathrm{e} 4266 \mathrm{bcc557d} 21 \mathrm{fd} 6 \mathrm{~b} 785 \mathrm{e}$ 